Article

\title{
Steering Energy Transitions through Landscape Governance: Case of Mathare Informal Settlement, Nairobi, Kenya
}

\author{
Peris Njoroge ${ }^{1, *}$, Amollo Ambole ${ }^{1}$, Daniel Githira ${ }^{2}$ and George Outa ${ }^{1}$ \\ 1 Institute of Climate Change and Adaptation; University of Nairobi, University Way, Nairobi 29053, Kenya; \\ lambole@uonbi.ac.ke (A.A.); outa@uonbi.ac.ke (G.O.) \\ 2 Physical Planner/GIS Analyst; Global Urban Observatory, UN Habitat, Nairobi 30030, Kenya; \\ dangithira@gmail.com \\ * Correspondence: perisnjoroge764@gmail.com
}

Received: 15 April 2020; Accepted: 15 June 2020; Published: 23 June 2020

check for updates

\begin{abstract}
Poor households in urban informal settlements face a big challenge in accessing clean energy for cooking, heating, and lighting. We use Kenya's Mathare informal settlement as a landscape site to better understand how cross-sector collaboration can enhance access to sustainable energy in informal settlements. We also demonstrate that academics are well-placed in facilitating multi-stakeholder engagements between community members, experts, and policy actors. This is pursued by drawing on the results of two energy research projects (CoDEC and AfriCLP). We employ a landscape governance framework to re-conceptualise the findings from the CoDEC and AfriCLP projects. Specifically, we use the ecological, socio-cultural, and political dimensions of landscape governance to discuss the relationships between energy demands and other landscape issues in the case study. In conclusion, the paper recommends landscape governance as a promising approach for integrating energy issues with other competing landscape interests, while also encouraging cross-sector collaboration.
\end{abstract}

Keywords: academic intermediaries; Kenya; landscape governance; sustainable energy; urban informal settlements

\section{Introduction}

Modern societies are grappling with the pressure of creating a balance between satisfying the needs of a fast-growing population and landscape conservation [1,2]. Population trajectories indicate that informality is likely to persist as more people move into urban areas [3,4]. Approximately, only $37 \%$ of the world's population lived in urban areas in the 1970s [5]. This number has nearly doubled with the 2018 world population report, indicating that urban landscapes were home to $55 \%$ of the world's population [6]. This figure is expected to rise to $60 \%$ by 2030 and $70 \%$ by 2050 [7]. Worldwide, it is estimated that 1 billion people live in urban informal settlements [8]. This trend leads to the assumption that as rural-urban migration continues, more people seeking cheap housing will continue to flock into informal settlements, making basic service provision more strenuous and further decreasing the sustainability of such landscapes [8-11]. This intensifies the need for implementation of strategies that can help provide sustainable energy transitions while also creating a balance between the synergies and trade-offs of urban informal landscapes in regard to energy, environment and community welfare [12].

Rapid and unplanned urban growth is also likely to exacerbate existing environmental and socioeconomic challenges plaguing urban cities of developing countries [3,4]. The demand for food and energy continue to grow as population increases [1]. Meanwhile, unsustainable land practices of both the present and past human generations contribute to land degradation and unsustainable use of natural resources such as rivers and forest landscapes [1,13]. This situation prioritizes the need to 
implement integrated restorative and conservation approaches to promote landscape resilience [14]. Conserving indigenous forests, promoting afforestation, reducing deforestation, and increasing access to clean energy are some of the approaches that actors can implement to create resilient landscapes [15]. Attempts to solve potential challenges of urban informality have heightened attention among academics, policymakers and community organizations to understand how to shape cities to improve the quality of life of urban dwellers while protecting the environment [12].

According to the United Nations Development Program (UNDP), 'Unsustainable patterns of energy production and consumption threaten not only human health and quality of life, but also deeply affect ecosystems and contribute to climate change. Sustainable energy, however, not only tackles these challenges head-on, but is also an engine for poverty reduction, social progress, equity, enhanced resilience, economic growth, and environmental sustainability' [16]. Enabling sustainable transition to clean energy in informal settlements is therefore an important strategy as it increases the chances of improving the environment and welfare of communities living there [15-17].

Urban informal settlements face various challenges that undermine their resilience and adaptation to climate change $[11,18,19]$. Their location in environmentally fragile landscapes such as steep slopes, riverbanks, and flood plains increases residents' exposure to climate hazards such as landslides and flooding [8]. The fact that most informal settlements are considered illegal makes it hard for national governments and local authorities to design frameworks to enhance their resilience $[8,11]$. Lack of spatial planning and insecure land tenure systems also affect efforts to govern and develop the landscapes on which the slums have been established $[17,18]$. Lack of infrastructure, illiteracy, and high levels of poverty further reduce the capacity of communities living in informal landscapes to transition to more sustainable livelihoods, including accessing safe energy [8]. Successfully adopting and implementing effective landscape approaches in such places is unpredictable. It requires a degree of muddling through, co-learning, adaptive planning, and creative design [20].

Urban development in Africa depicts a diverse and ambivalent phenomenon whose aspects do not fall neatly into global development standards [21]. About $59 \%$ of urban dwellers in Sub Saharan Africa live in informal settlements [9]. Different informal settlements pose different challenges [17,22]. Governance and development efforts in Kenya and other developing countries often misinterpret the needs and challenges of urban informal settlements [23]. To meet these complex challenges, many actors have recommended multi-stakeholder engagement as a plausible approach $[17,18,24,25]$. However, little is known about how multi-stakeholder engagement can be facilitated to achieve long-lasting change in informal landscapes [18]. One of the two projects discussed herein was a multi-country research project titled Co-Designing Energy Communities with Energy Poor Women in Urban Areas, (in short CoDEC) ${ }^{1}$. This was a two-year study on household energy in informal settlements in Kenya, Uganda, and South Africa (see ref. $[17,18]$ ). The study highlighted the role of academics as knowledge intermediaries and change agents who can trigger cross-sector collaborations around innovations for sustainable energy transition in cities [18]. In this case, the researchers set out to better understand how sustainable energy solutions in urban informal settlements can be achieved through collaborative efforts between community members, experts, and policy actors. The second project was follow-up expert interviews under the AfriCLP program where we set out to gather views from policy actors. In both projects, a transdisciplinary co-design methodology proved to be a promising approach for facilitating multi-stakeholder engagements. In the present paper, we widen the scope of the co-design process using a landscape governance framework.

The use of landscape approaches is increasingly gaining prominence as a methodology for effectively adapting to climate change, reducing disaster risk, and enhancing community resilience [26]. Principles of landscape governance and landscape approaches are anchored by the concept of multi-stakeholder participation [24]. The widely accepted 'Ten Principles of an Adaptive Landscape

1 http://codec.livinglab.co.ke/. 
Approach' proposed by Sayer et al. reflect the participatory nature of landscape approaches and how they are entrenched in a process of multi-stakeholder governance at the landscape level [24]. Landscape governance primarily relates to how decision-making addresses various conflicting interests in the landscape [25]. It also relates to how the decisions made encourage collaborations among stakeholders and stimulate sustainable management of the landscape [24,27]. For this paper, we define landscape governance as the taking of collectively binding decisions considering the landscape, its use, and its development [28]. This perspective acknowledges that numerous actors are involved in the decision-making processes and development of policies and other interventions that impact the landscape.

The objective of this paper is to explore how landscape governance can help frame transitions towards sustainable energy. The paper also highlights the role of academics in facilitating multistakeholder engagements upon which landscape governance and sustainable energy transitions are anchored. Within this framework, we examine the constraints faced in establishing cross-sector collaboration and present our transdisciplinary co-design methodology as a promising approach in enhancing urban services in contested landscapes where various land uses compete. We argue that standardised and technocratic top-down approaches fail to deliver development and access to sustainable clean energy in urban informal settlements. We underscore the importance of implementing an adaptive and multi-layered cross-sector collaboration approach and the need to view energy through a landscape governance lens. Our paper indicates a need to understand and appreciate the underlying issues that lead communities in urban informal settlements to make the choices that they make. The suggestions herein should help inform the development of effective energy transitions and landscape governance policies.

\section{Case Study: Mathare Informal Settlement}

Informal settlements house over half of Nairobi's population, yet occupy only $5 \%$ of the residential area and just $1 \%$ of the total Nairobi land area [29]. Most urban centres in Kenya were established during the colonial era as seats of the British colonial government [23]. Segregation of White and Native residential areas created a basis upon which a skewed system of land distribution was formed [20]. Following the colonial legacy, Nairobi was racially zoned, and the native urban poor were ghettoised in the outskirts of the city [23]. The end of colonialism did not solve the issue of unequal land distribution. Land arbitration by the post-colonial government did little to settle the landless citizens, and as a result, led to the formation of numerous informal settlements to house the native squatters $[20,23,30]$. These informal settlements mostly occupied the poorest quality lands due to a lack of formal systems to provide affordable serviced land $[8,29]$. We chose the Mathare informal settlement as our landscape site (Figure 1).

Like many other slums in Kenya, Mathare informal settlement in Nairobi, as it is known today, was established in the 1960s shortly after Kenya gained independence in 1963 [31]. This informal settlement is the second largest in Kenya after Kibra. Informally, it is comprised of 13 villages across a land of roughly three-square miles (Figure 2). The larger Mathare sub-county is home to 206,564 people, resulting in a population density of 68,941 per square kilometre [32]. Residential land use dominates all other land uses in the Mathare area. The landscape is characterised by hundreds of structures laid haphazardly without any structural or spatial planning. The other land uses in the settlement are for commercial and public purposes, but this only takes a small percentage.

In terms of the physical and natural characteristics, the informal settlement is a flood plain located along Mathare River. This overly polluted river [33,34] is one of the three tributaries of the Nairobi River Basin. It connects Mathare informal settlement to Kiambu County upstream and Lower Eastern and Coastal Counties downstream. About 30\% of Mathare Valley falls within the 30-metre riparian reserve (Figure 3) $[20,23]$. The landscape slopes from west to east and towards the river channel. The soils are a mixture of alluviums, black cotton, and red clay, thereby making some parts of the settlement relatively unstable in regard to bearing capacity [20]. It features various areas that were previously quarry sites 
and are presently characterised by steep riverbanks. Some of these areas remain uninhabited due to their rocky terrain and steep gradients. The settlement has been an arena of unending land disputes between the government authorities and private investors, tenants, and structure owners, and is often characterised by numerous evictions and arbitrary demolition of structures [23].

\section{Context Maps for Mathare Informal Settlements in Nairobi}

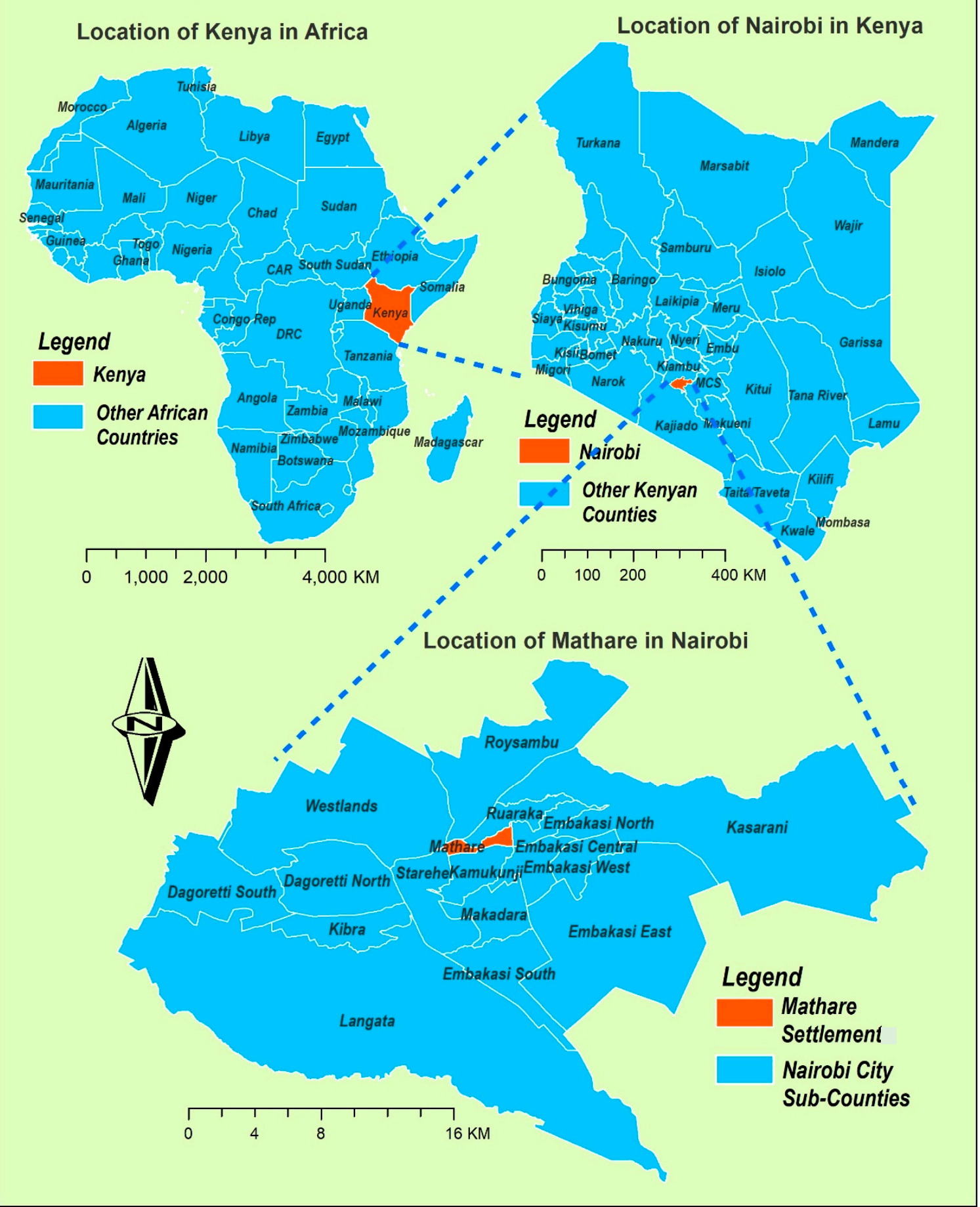

Figure 1. Location of Mathare informal settlement in the context of Africa (Source: authors). 


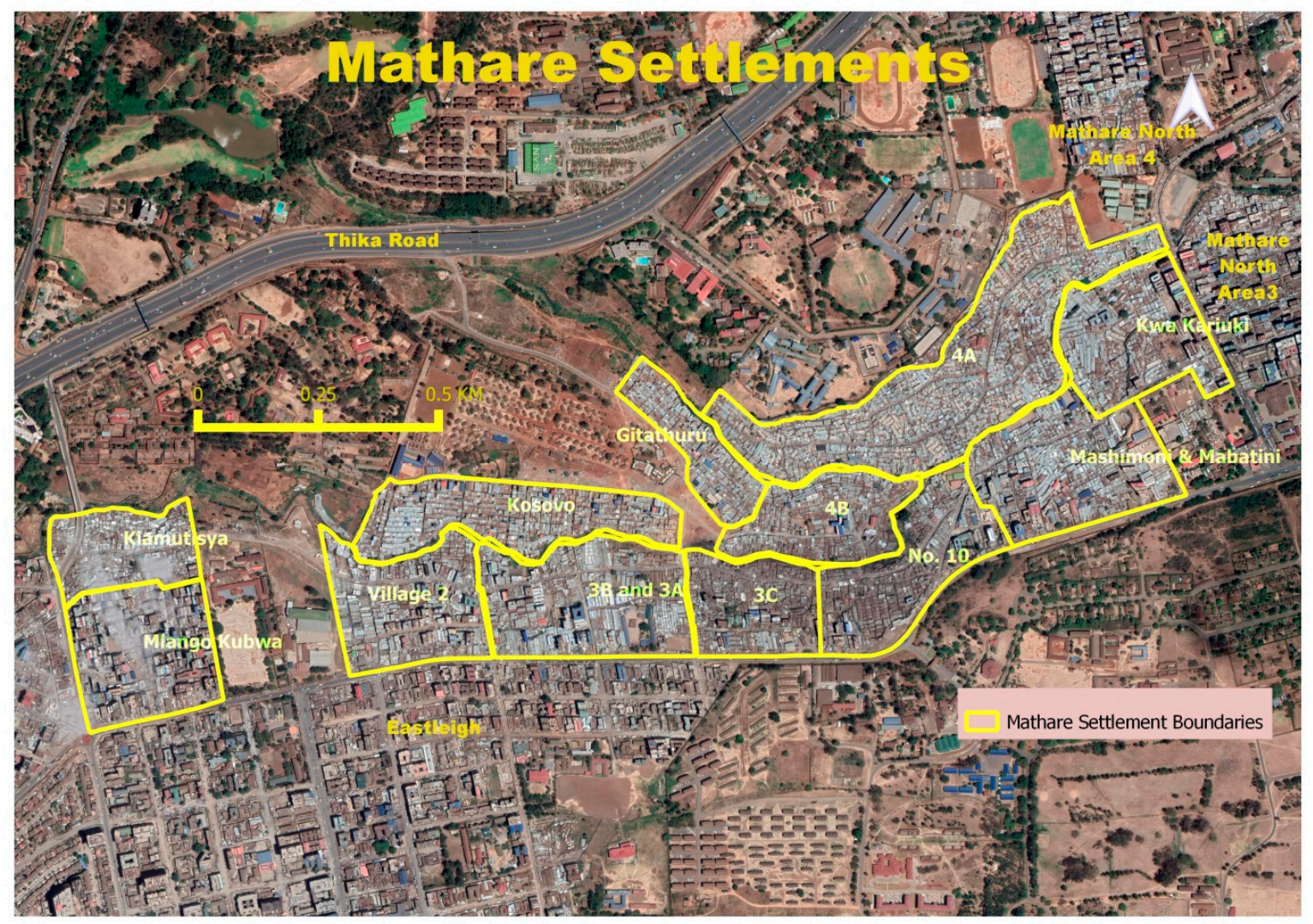

Figure 2. Mathare informal settlement in Nairobi (Source: authors).

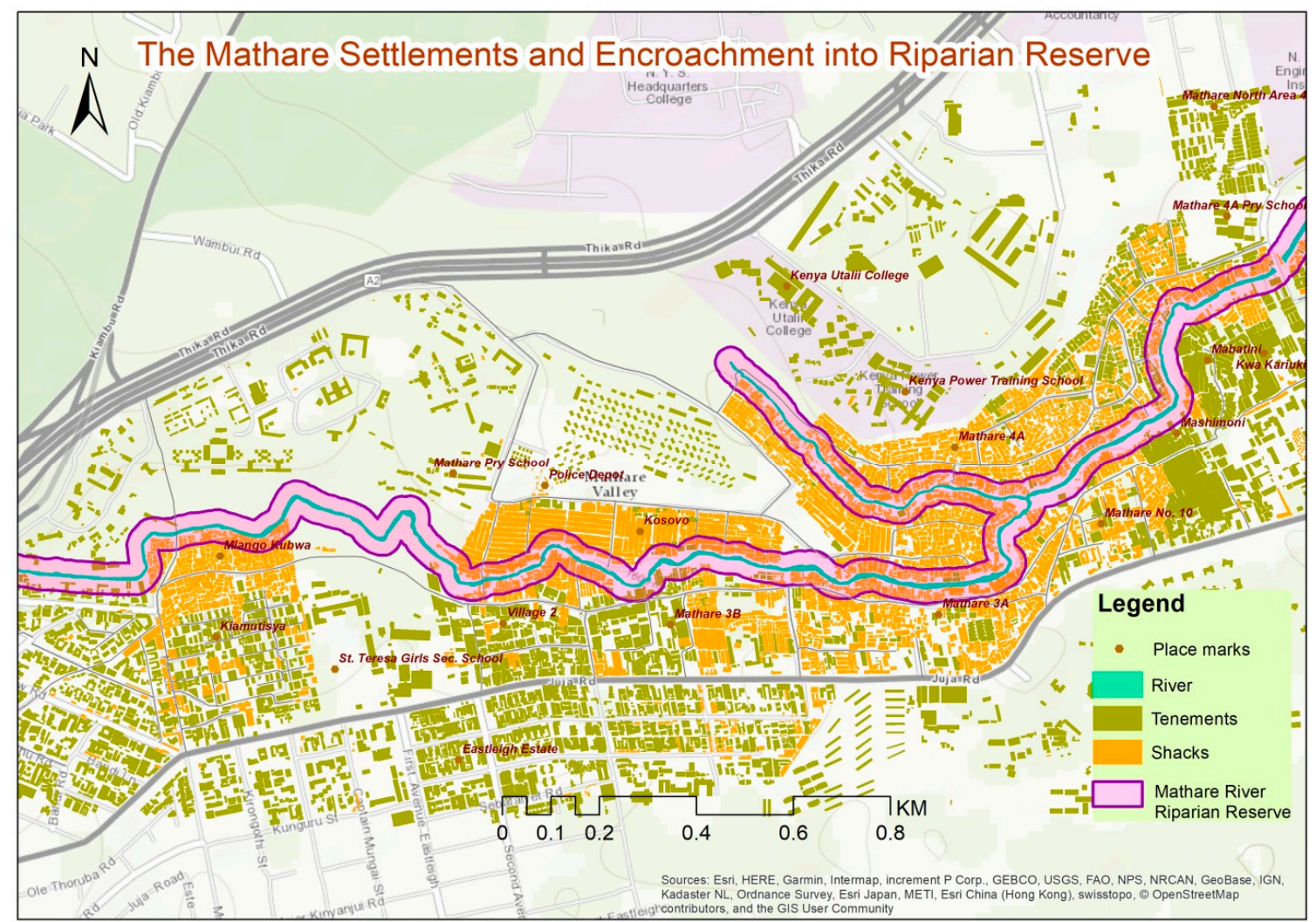

Figure 3. Map showing human encroachment along the Mathare River (Source: authors). 


\section{Material and Methods}

This paper builds on previous data and lessons generated by an interdisciplinary research team on the multi-country research project titled Co-Designing Energy Communities with Energy Poor Women in Urban Areas (in short CoDEC) and follow-up expert interviews in Nairobi under the AfriCLP program (see ref. [17-19]). Using Mathare informal settlement as the case study in Kenya, the team held workshops, a policy seminar, and key informant interviews. These brought together participants from Mathare informal settlement: Residents, community leaders, energy service providers; Policy actors from: Nairobi County government, Nairobi County Council (Health department), Ministry of Energy, Kenya Power and Lighting Company (KPLC), the Energy and Petroleum Regulatory Authority (EPRA); and researchers and experts from: The University of Nairobi, Stockholm Environment Institute (SEI), IRD-Kenya, and the Kenya Institute for Public Policy, Research and Analysis (KIPPRA).

In the two-year study, CoDEC researchers used participatory research methods to facilitate knowledge co-production and solution co-design. The team engaged community members in carrying out household surveys and participatory GIS mapping to establish the socio-spatial, economic, and cultural dimensions of energy, in relation to energy and health outcomes. The case study was selected through convenience sampling because the researchers had prior research experience with Mathare. This enabled them to leverage existing relationships and work with participants who were easily accessible and willing to participate in the survey. In an initial baseline study, research questionnaires were distributed to 100 households within the settlement. The questionnaires were administered by trained field workers drawn from the community and researchers from the University of Nairobi. The survey provided insights into the energy situation in the settlement in relation to health perceptions and other socio-economic factors. The survey was followed by two focus group discussions with residents to deliberate on factors such as the quantitative findings, gaps, and inconsistencies in the data collected. Each focus group had 20 participants. The preliminary findings were used to engage energy and health experts, community members, and government officials in a co-design workshop (19 participants), policy seminar (27 participants), and a dissemination workshop (20 participants) between 2017 and 2018. The co-design workshop was held to come up with energy system options for Mathare. The purpose of the policy seminar was to discuss policy options for the energy-health nexus in Kenya. The dissemination workshop was held to launch "Mathare energy stories" booklet, which contained highlights from the household survey and comic strip illustrations of energy stories as told by Mathare community members. Through these engagements, the researchers were able to relate the context-specific energy challenge in Mathare to the broader energy market and policy environment in Kenya. A regional workshop for CoDEC regional partners was held in 2019 to engage stakeholders in Kenya and discuss comparative analyses of case study findings (39 participants). This study enabled the researchers to identify constraints that hinder clean energy transitions in informal settlements and circumstances that necessitate the use of traditional fuels such as charcoal.

In a follow-up project under the AfriCLP program, the researchers used findings from the CoDEC study and carried out six key informant interviews between October and November 2019 to develop a policy brief to propose electricity subsidies for informal settlements. This was used as a basis for gathering further insights from research and policy actors (see ref. [19]). Respondents for the key informant interviews were drawn from the Ministry of Energy, County Government of Nairobi, Kenya Power and Lighting Company (KPLC), Energy and Petroleum Regulatory Authority (EPRA), Stockholm Environment Institute (SEI), and Kenya Institute for Public Policy and Analysis (KIPPRA). This enabled the researchers to identify various constraints that hinder multi-stakeholder engagement and cross-sector collaborations between actors involved in policy and governance and local communities. The CoDEC research and the follow-up project under AfriCLP program identified the need to bring together the diverse range of stakeholders and establish viable pro-poor energy solutions that can help meet the objectives of Kenya Vision 2030 policy blueprint while also ensuring sustainable energy access for all as subsumed under the global SDG $7[4,17,18]$. 
In this paper, we use a landscape governance framework to re-conceptualise the findings from the CoDEC and AfriCLP projects. Specifically, we used three landscape governance dimensions namely the ecological, socio-cultural, and the political dimension to discuss the relationships between energy demands and other landscape issues in the case study.

\section{Results}

The research interactions in the CODEC and AfriCLP projects unearthed various constraints faced in establishing cross-sector collaboration in the energy sector in Kenya. To meet this challenge, the researchers proposed transdisciplinary co-design as a collaborative approach that can enhance multi-stakeholder engagement and cross-sector collaborations towards access to sustainable household energy in urban informal settlements. Lessons from the CoDEC project and insights gained from the Key Informant Interviews under the AfriCLP project demonstrated the role and importance of academics in facilitating multi-stakeholder collaborations. By framing Mathare as a landscape site in this paper, we further highlight the energy challenge in informal settlements in relation to landscape governance. We thus emphasize how cross-sector collaboration is crucial for the provision of urban services in contested landscapes where various land uses compete.

The results are presented in two parts: (Section 3.1) Findings from the two-year CoDEC project, and (Section 3.2) Findings from the follow-up interviews under the AfriCLP project.

\subsection{Findings from The Two-Year CoDEC Energy Project (2017-2019)}

\subsubsection{Energy Scenario and Challenges to Sustainable Energy Transition}

The baseline study revealed that $93 \%$ of the Mathare households in our survey were connected to the national grid. However, $50 \%$ of these connections were illegal and unmetered, as they were not provided directly by the legal utility provider, Kenya Power and Lighting Company. Respondents cited the high cost of legal connection and monthly charges as factors influencing their preference for illegal connections. Charcoal was the second most preferred fuel after kerosene for heating, cooking, and boiling water (see ref. [17]). Other fuels used within the settlement include liquefied petroleum gas and electricity. The price of the fuels was a major factor in determining the household's fuel preference and energy consumption. Dependence on multiple fuels was a way to make households more resilient to fluctuation in prices of charcoal, gas, and kerosene in the face of unaffordable electricity [18]. Respondents also preferred kerosene to charcoal because it is relatively clean and emits less smoke. Lack of spatial planning was evident and was cited as one of the challenges hindering effective service provision within the settlement. Structures are laid out haphazardly across the landscape. The development of infrastructure adds to the competing uses that put pressure on the already scarce space. The researchers estimate that only approximately $4 \%$ of the total land area in Mathare is left for movement and circulation [20]. As a result, there are limited access roads for vehicular movement. This is a challenge especially for service providers such as Kenya Power and Lighting Company, who need access into the interior areas to erect electricity poles and transformers. Accidental fires from the use of candles and kerosene stoves are a common phenomenon. The lack of access roads is a major hindrance to emergency fire response units.

\subsubsection{Land Issues}

Mathare informal settlement is a combination of private and public land. Some parts are owned by the Government of Kenya, while others are owned by private local investors. Presently, most of the residents in Mathare are tenants. In our study, $73 \%$ of the survey respondents were tenants, while $27 \%$ were structure owners. The main challenge posed by this is the lack of security of tenure as the occupiers do not have title deeds or lease letters for the land on which they live. According to Arts et al. and Heiner, Shames and Spiegel, communities are more likely to engage in pro-environmental activities and take better care of their landscapes if they have land ownership and feel a sense of belonging $[14,25,35]$. 
Due to the lack of title deeds and other land ownership rights, residents of Mathare live in fear of eviction, and therefore do little to manage or develop their spaces [23]. Customers are required to provide proof of land ownership to the utility provider for legal connection [20]. Lack of security of tenure therefore hinders Mathare residents from accessing legal power connections that would enhance their access to clean energy for cooking, heating, and lighting. As a result, the majority opt for traditional sources of energy such as charcoal and firewood whose excessive use contributes to environmental degradation, deforestation, and increased health risks because of indoor air pollution [17,18].

\subsubsection{Livelihood Issues}

The study established that basic service provision in Mathare is either extremely poor or entirely non-existent. The supply of clean water, and collection and disposal of waste are left to private contractors. Dumping into the Mathare River, along the riverbank, and on the sides of the road is rampant. In a focus group discussion, residents complained of lack of clean and safe water for drinking and their daily use. Although the Mathare River runs through the informal settlement, pollution is high [34]. Different types of household refuse, raw sewage, and solid wastes are dumped into the river, thereby making the water unfit for human consumption. It should be noted that the livelihoods of people downstream in the lower Eastern and Coastal regions of Kenya depend on water from the Nairobi river basin (made up of Mathare River, Nairobi River, and Ngong River) for their daily use (Figure 4) [23].

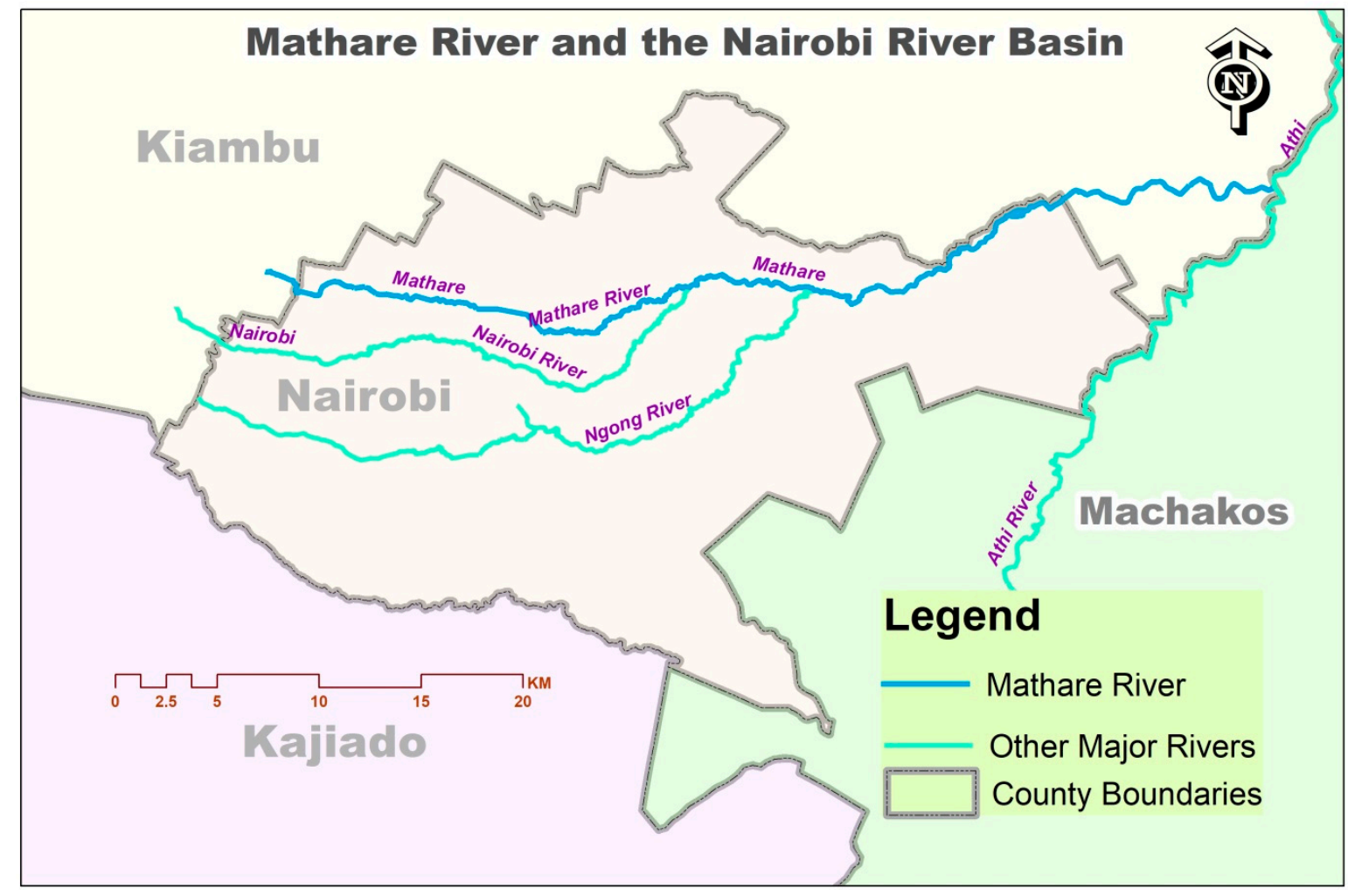

Figure 4. River connects landscapes in different counties (Source: authors).

Pollution of the Mathare River, therefore, affects people within and outside the informal settlement. This necessitates a cross-border collaboration of actors in all the landscapes where the river traverses if rehabilitation and conservation approaches are to be effective [36]. 


\subsection{Findings from The Follow-Up Expert Interviews under AfriCLP Program (2019)}

From the interactions with Mathare residents and interviews with key informants, the researchers identified the following as constraints to establishing multi-stakeholder engagement and cross-sector collaborations:

\subsubsection{Lack of Consensus}

It became apparent that different agencies had different views concerning the same issues. Some of these views from the utility provider (KPLC) and the utility price regulator (EPRA) contradicted each other. Whereas KPLC maintained that it was impossible to provide lower electricity tariffs for communities living in urban informal settlements, EPRA maintained that it was possible to provide lower tariffs for those residents. Our engagement with community members revealed that residents were willing to get legal connections, but only if the cost of connection and monthly power bills were affordable. This lack of consensus between the two key actors in the energy sector hinders collaborative efforts towards enhancing the transition to clean energy in informal settlements.

\subsubsection{Mistrust between Residents and Government Actors}

The residents lacked faith in government actors and utility providers. They expressed doubt on whether the government would act in the community's interest. On the other hand, the county and national governments continually fail to recognize the legitimacy of informal settlements. The 6th principle of Sayer et al.'s 'Ten Principles of an Adaptive Landscape Approach' states that trust among stakeholders is crucial in creating negotiated and transparent change logic [24]. Trust is important in structuring mutual relationships. It can influence public support for policies, enhance productive cooperation and promote open dialogue among stakeholders [37,38]. Existing mistrust between government actors and residents of Mathare informal settlement is a barrier to collaborations aimed at developing an effective governance model for the Mathare landscape. This mistrust exacerbates security risks. The utility provider cited insecurity and rampant attacks on its officials during work visits to the informal settlement as one of the major hindrances to provision of electricity in Mathare. The researchers conclude that there is need to invest in understanding the needs of energy consumers and build a relationship of trust particularly between informal settlement dwellers, government, and service providers. Creating a platform for government officials, experts, and community members to co-design solutions together is one way of dealing with trust issues and enhancing security.

\subsubsection{Cultural, Social, and Economic Barriers}

Residents' perceptions and financial constraints hinder them from embracing a technology switch to cleaner energy. This was attributed to the cost of legal connection and the cultural belief that charcoal is best for cooking certain traditional meals. This is in line with Sayer et al.'s argument that multiple stakeholders form their objectives differently [24]. Therefore, conflict or lack of understanding of the underlying factors that shape the stakeholders' preferences and objectives hinders any meaningful governance, clean energy dialogues, and cross-sector collaboration [14].

\subsubsection{Lack of Awareness at the Sector and Community Levels}

This emerged as a barrier to cross-sector collaboration. Knowledge transfer and awareness creation are crucial in ensuring effective multi-stakeholder engagements $[18,24]$. The rights and responsibilities of stakeholders need to be clarified and well-understood for effective collaboration to take place $[8,24,25]$. Some of the stakeholders did not know much about the other actors. In one of the workshops, a government agent involved in policy formulation confessed to having never visited Mathare informal settlement before. On the other hand, some of the residents were not aware of the government agencies and their mandate. The CoDEC project researchers created a platform for both parties to engage and learn about each other. 


\section{Analysis of CoDEC and AfriCLP Results through a Landscape Governance Framework}

Analysing clean energy transition through a landscape lens requires an understanding of how the two are related. Energy transitions and landscape governance can be understood from ecological, social-cultural, political, and environmental dimensions. In this section, we use the CoDEC and AfriCLP findings to demonstrate how clean energy transition can be understood using a landscape governance framework. We start by creating a link between energy transitions and different dimensions of landscape governance.

\subsection{Ecological Dimension}

Landscapes provide the context for the lived experiences of humans and their communities. It is where ecological and social histories are shared [39]. Here, the creation of and participation in shared knowledge and development occurs [40]. Effective landscape approaches need to be based on an understanding of the natural-ecological characteristics of the area [25,41]. This allows a fully integrated and effective framework to be developed. This is to say that formal and informal urban dwellings in Sub-Saharan Africa can perform satisfactorily if the larger environment functions properly as a living space. This is largely determined by how communities within the respective landscapes manifest themselves outwardly and how they interact with their living spaces [21]. County and national governments need to acknowledge that despite their segregation, informal settlements do not thrive in isolation of the landscapes around them [8,42]. What happens in Mathare affects other landscapes and natural resources. For example, lack of access to electricity compels residents to rely on charcoal and firewood for their cooking and heating needs. As a result, (1) Use of charcoal contributes to deforestation and land degradation due to excessive tree logging [43,44]; (2) burning of charcoal leads to the release of carbon monoxide, nitrogen oxides, formaldehyde, benzene, and other hydrocarbons into the atmosphere, thereby contributing to climate change $[18,45,46]$; and (3) the smoke emitted during combustion of charcoal in poorly ventilated houses increases the health risk of the users $[17,18,46]$. Transitioning to clean energy and increasing access to electricity will, therefore, benefit forest landscapes, help in the fight against climate change, and contribute towards improving the livelihoods of informal settlement dwellers.

\subsection{Socio-Cultural Dimension}

Part of what makes us human is that, unlike other animals, we can philosophize about our place in the world and can experience existential crises [40]. Sense of place and socio-cultural identity are crucial factors in landscape governance [25]. The socio-cultural dimension of landscape approaches is philosophised through various cultural practices, beliefs, and heritage $[1,47,48]$. Culture impacts people's choices and how they use or add value to natural resources [24]. The multi-level transdisciplinary co-design methodology enabled the CoDEC researchers to assess monetary and non-monetary factors that shape residents' choice of fuel and what prompts them to prefer charcoal despite the negative impacts associated with it $[17,18]$. It was discovered that charcoal is culturally viewed as a better fuel for cooking certain traditional foods $[17,18]$. Therefore, changing the community's energy behaviour and land use practices requires one to understand the culture and the factors that inform their decisions and preferences [24,39]. This approach is important in collaborative stakeholder engagements because it creates a platform for respondents to conceptualize why others do what they do. Contestations may arise, but solutions arrived at after deliberations are usually more inclusive and stand a higher chance of acceptance at the community level [49-51].

\subsection{Political Dimension}

In policy and planning, landscapes are often understood as administrative territories that are geographically bound and subject to formal territorial and institutional policy and planning interventions $[25,41,52]$. However, management approaches that are implemented in isolation do 
not suffice [1]. Lessons drawn from the CoDEC and AfriCLP projects point to the need to expand the scope and make formal and informal institutions work across the borders to ensure genuine integration. The role of landscape approaches is to provide a framework to integrate practice and policy for different land uses in each area [1]. A lot of learning and knowledge co-creation is involved to achieve integration [10]. Through co-design workshops, academics create a platform where policy and planning actors can clarify rights and responsibilities relating to land and resource use to community stakeholders [24]. In Mathare, this remains elusive due to lack of land ownership rights and security of tenure and mistrust between the government agents and the local community $[17,18]$. Arguably, the fact that residents live in constant fear of eviction undermines their ability to support or implement long-term sustainable landscape approaches [14]. The study concludes that policy and planning initiatives have failed to devise sustainable energy and landscape governance approaches for the Mathare landscape.

\subsection{Environmental Dimension}

It has been argued that the analysis of 'energy' as a generic concept fails to capture differences in energy use [17]. This means that policies that are only aimed at shifting overall consumption towards electricity and away from traditional fuels are unable to adequately address the clean energy needs of the urban poor. It would be incorrect to infer that increased electrification will automatically lead to lower consumption of charcoal. However, this coupled with effective environmental policies and landscape approaches may significantly reduce the consumption of charcoal and firewood [43]. For example, in 2017 the Government of Kenya imposed a ban on tree logging and charcoal production in public forests. The aim of this charcoal ban policy was to increase the country's forest cover to at least $10 \%$ and reduce the widespread use of charcoal $[43,53,54]$. The ban led to an increase in the cost of charcoal across the country $[17,18,44]$. Market logic dictates that an increase in the cost of charcoal will drive consumers to switch to alternative sources such as electricity [43]. However, this logic failed to take effect in Mathare, as the majority cannot afford legal connection because of their meagre earnings at an average of Ksh. 18,000 per household [17]. The moratorium on logging and lack of affordable alternatives to charcoal led residents to switch to sawdust as a fuel [18].

\section{Discussion}

Implementation of effective landscape approaches calls for an iterative process of trial, learning, and adaptation that is designed to meet the specific socio-spatial conditions of the area [25]. Governance of informal settlements is complicated by the lack of defined landscape approaches and implementation blueprints. Academics are increasingly playing pivotal roles in leading the learning processes and facilitating actor-collaborations and multi-stakeholder engagements as was demonstrated in the CoDEC project, thereby becoming the much-needed change agents in solving some of the world's most pressing urban challenges $[15,18,55,56]$.

\subsection{Landscape and Energy Policy Interventions}

In policy and planning, landscapes are often viewed as administrative territories that are geographically bound and thus subject to territorial policy and planning interventions [25,52]. This paper emphasizes the importance of widening the scope and creating actor-networks that move beyond geographical boundaries [27]. We maintain that sustainable and effective landscape governance requires the creation of networks that transcend the boundaries and connect sustainable interventions across different landscapes and different administrative areas $[25,57]$. For example, a river connects different areas and varied activities across different administrative territories both upstream and downstream [8]. This means that the illegal dumping of solid wastes and household refuse done on Mathare River affects Mathare residents and communities downstream who depend on the river [36]. Multi-level collaboration characterised by multi-stakeholders and multi-sector engagement is thus required in the governance of the Mathare landscape and others that are connected to it. Energy 
transition strategies also need to be driven by the same principle of multi-stakeholder collaborations across different sectors and government levels $[17,18,58]$. Through a landscape approach, stakeholders can view energy issues from a landscape perspective.

Lessons can be drawn from countries such as Chile and Brazil, where residents exchange recyclable wastes for a reduction in their electricity cost. In 2007, the 'Ecoelce' initiative was launched in Brazil. The program allowed exchange of recyclable garbage for a bonus in the electricity bill [59]. It is estimated that the program led to proper disposal of over 18,500 tons of waste in Fortaleza. The success of this program saw it replicated in Santiago and Rio de Janeiro in 2010 [59]. Initiating such a project in Mathare would help solve the challenges of waste disposal and ease the cost burden of accessing legal electricity connection. The focus will shift from just increasing access to electricity to ensuring that residents access this energy in ways that are not detrimental to the environment, natural resources, and the safety of other people within and outside the landscape [17,18]. Such projects require investment of human, technical, and financial resources from diverse stakeholders. Therefore, there is need to develop close working relationships between government agencies, academics, and residents of informal settlements to allow the stakeholders to co-explore relevant issues and coproduce potential solutions $[3,18]$.

\subsection{Failure of Standardised Policy Interventions}

Current landscape and policy interventions do not adequately address the land and clean energy issues in Mathare informal settlement. From the CoDEC research, the team concluded that Kenya's energy policy and regulations are highly standardised and might therefore not work for the urban informal settlement dwellers $[17,18,22]$. The takeaway point from this paper is that urban informality cannot be understood through standardised measurements because different informal settlements raise different challenges of understanding and governance. Clean energy transitions and governance of informal settlement landscapes cannot therefore be governed through blueprint or standard policy interventions [17]. Universal electrification is one example of a standardising policy that has failed to work in solving energy challenges of informal settlements. For example, in South Africa, a solar power project was established in 2011 in Enkanini informal settlement to achieve the goal of universal electrification [10]. The project improved safety through street lighting but failed to substitute the use of multi-purpose fuels such as charcoal and kerosene. A similar biogas initiative was once implemented in Mathare but failed after one year because of capacity limitation and lack of community support.

Africa leads the world in the adoption of pre-paid electricity systems that have worked well in South Africa and in Kenya [59]. However, when the pre-paid system was introduced in Mathare, the residents used it for a few months before reverting to the illegal connections that were cheaper than the pre-paid system because illegal connections are not metred. During the workshops and focus group discussions, residents attributed the initiative's failure to lack of consultation between the community, government, and utility provider. In the key informant interviews, representatives from the utility provider and regulator attributed the failure to residents' unwillingness to switch from illegal connection. Evidence of interventions working in some areas and failing in others demonstrates that community initiatives are likely to work better if they are informed by context-specific needs and experiences of residents $[17,30,42,59,60]$.

Similarly, environmental policies implemented by the Government of Kenya to reduce deforestation and protect the environment would work better if access to alternative and safe energy in affected landscapes is increased. Implementation of one in the absence of the other will do little to solve the underlying problems [61]. The charcoal ban policy in Kenya was a top-level intervention implemented at the national level. Failure of top-down approaches to decision-making and policy development is increasingly becoming evident $[49,62,63]$. A more bottom-up approach where stakeholders are included is increasingly gaining prominence as a more appropriate mode of decision making to address the complexities of urban development [62]. Co-designing solutions with the local stakeholders ensures inclusion in decision making and increases the chances of developing integrated policies that work for 
the local community [64]. According to Beunen and Opdam, successful solutions are only developed in collaboration between practitioners, local communities, and researchers [65]. This marks a shift from government to governance where the need to coordinate between multi-stakeholders and resources is emphasised [49]. Only then can place-based solutions be created and implemented for effective long-term change.

\subsection{Academics as Intermediaries of Change and Knowledge Co-Creation}

By acting as intermediaries and catalysts of change, academics facilitate co-learning and co-design of solutions among different stakeholders [18]. The term landscape approach captures and is founded on the aspiration of a transdisciplinary approach and collaborative governance $[24,52,59,66,67]$. A key similarity between a transdisciplinary co-design approach and a landscape governance approach is that both aim to foster cross-sector collaboration using co-creative methods that are effective, iterative, and integrative [18,50]. These approaches help actors to move from a business-as-usual model [68] and embrace more participatory co-learning approaches that aim to build a meaningful consensus between multiple stakeholders [18,69]. Translating knowledge into action that allows mitigation, adaptation, and landscape solutions in informal settlements is a challenge [66]. Overcoming this challenge calls for multi-level governance that is based on learning and knowledge co-production in concrete human-nature systems (i.e., Landscapes) [24]. Transdisciplinary research entails collaboration and knowledge co-creation between different communities of place and practice and is, therefore, an effective avenue for translating knowledge into action $[10,66]$. In the CoDEC research, the transdisciplinary approach was anchored on the place-based realities of residents in Mathare [17,18]. Community members exchanged ideas with policymakers on how best to deal with the issue of illegal connection and cartels' operations in the informal settlement. Such encounters are steps towards building trust, consensus, and creating positive change and sustainable transitions in informal landscapes.

Building consensus requires acknowledgment that different stakeholders often have contrasting views and competing interests [24]. In addressing the interrelations between clean energy and landscapes, Zoellner et al. regard societal acceptance as the ideal worth striving for [70]. Conflict and disagreements are problems that should be avoided. On the contrary, Leibenath and Lintz and Carvalho et al. argue that the adoption of democratic principles of contestation and competition of ideas is more important [51]. The idea here is that competing ideas are effective in exposing salient issues and enhancing strong collaborations [50,51]. In support of Leibenath and Lintz's and Carvalho et al.'s argument, we believe that a transdisciplinary co-design methodology to energy and landscape governance is a promising approach. In the CoDEC project, stakeholders gave different ideas to solve the challenges facing Mathare. These varying ideas were iterated through the University of Nairobi Living Lab to ensure that stakeholders' views were captured, and common solutions developed [71]. This led to the creation of a strong actor-network that would allow the delivery of place-based solutions $[17,18]$. This enhances the translation of knowledge into action that allows mitigation and adaptation measures to be implemented [15].

\subsection{Recommendations}

Urban energy landscapes emerge from the coevolution of socio-ecological and socio-technical systems. They are heterogeneous, diverse, and require context-based interventions for success [72]. Table 1 shows place-based interventions that have been implemented in various informal settlements around the world. Some of these interventions can be adopted and adapted for the Mathare landscape. 
Table 1. Summary of initiatives that can be implemented in Mathare: Lessons from other areas (Source: authors).

\begin{tabular}{|c|c|c|c|c|}
\hline Initiative & Places Where Implemented & What Worked & What Has Not Worked & Viability in Mathare \\
\hline $\begin{array}{c}\text { Universal } \\
\text { electrification }\end{array}$ & $\begin{array}{l}\text { Enkanini (Solar project) } \\
\text { Mathare (Biogas project) }\end{array}$ & $\begin{array}{c}\text { Improved safety through street } \\
\text { lighting }\end{array}$ & $\begin{array}{l}\text { Failed to significantly curb the } \\
\text { use of charcoal and paraffin }\end{array}$ & Biogas project failed \\
\hline $\begin{array}{l}\text { Pre-paid electricity } \\
\text { system }\end{array}$ & South Africa; Kenya & $\begin{array}{l}\text { Consumers are able to access clean } \\
\text { energy within their budget }\end{array}$ & $\begin{array}{l}\text { The system could be limiting for } \\
\text { people of low income }\end{array}$ & $\begin{array}{l}\text { The pre-paid system failed in } \\
\text { Mathare because it cost residents } \\
\text { more than what they pay for the } \\
\text { illegal connection }\end{array}$ \\
\hline $\begin{array}{l}\text { Recycling for } \\
\text { electricity credit }\end{array}$ & Chile, Brazil & $\begin{array}{l}\text { Dumping is reduced through } \\
\text { recycling. } \\
\text { It eases the expenses of paying for } \\
\text { electricity }\end{array}$ & & $\begin{array}{l}\text { Could be considered as a long-term } \\
\text { project to reduce the menace of } \\
\text { illegal dumping along the roads } \\
\text { and banks of Mathare River. }\end{array}$ \\
\hline $\begin{array}{l}\text { Slum regeneration and } \\
\text { recognition projects }\end{array}$ & Peru, Brazil, China, Indonesia & $\begin{array}{l}\text { Titling has given informal settlements } \\
\text { land ownership that allows them to } \\
\text { develop their landscapes and have a } \\
\text { sense of identity and belonging. } \\
\text { Regeneration projects have allowed } \\
\text { upgrading of houses in the informal } \\
\text { settlements to allow better provision } \\
\text { of services and essential amenities }\end{array}$ & $\begin{array}{l}\text { Regeneration projects have led } \\
\text { to demolition of structures } \\
\text { during the upgrade and thus } \\
\text { failed to secure housing for all } \\
\text { residents as some had to move } \\
\text { to other peri-urban areas [30]. }\end{array}$ & $\begin{array}{l}\text { Titling allows residents to have } \\
\text { legal ownership and } \\
\text { documentation required by the } \\
\text { utility provider to provide access to } \\
\text { the grid. This is a potential solution } \\
\text { to Mathare's energy issues. }\end{array}$ \\
\hline
\end{tabular}


From the foregoing, this paper recommends that a landscape governance approach should be adopted when designing solutions for informal settlements to safeguard the environment and community interests. Strategies and approaches to sustainable energy transitions and landscape governance should be adapted to the changing societal demands and shifting opportunities for planning and policy making. Incentives in terms of safety, pricing, and security of supply should be provided to encourage informal settlement dwellers to switch to legal connections. Co-design of centralised solar power and biogas energy stations with residents should be explored as an alternative for supplying the community's energy needs with affordable renewable energy. Developing the energy stations with the community gives them a sense of ownership and the projects are more likely to succeed. The government could also consider providing special electricity tariffs for informal settlements to reduce the cost of connections and power supply. This will incentivise them to seek legal, safe connections. More importantly, this paper recommends and emphasizes the importance of policy actors and regulators investing in understanding the needs of consumers. This will help to build relationships of trust between residents, government, and service providers through multi-actor collaborations.

\subsection{Limitations}

The aim of the CoDEC and AfriCLP projects discussed in this paper was to establish long-term cross-sector collaborations that would lead to sustainable energy transitions in urban Africa. As a result, the researchers in these projects did not provide concrete technical solutions that can be implemented in the case study. The researchers argue in this paper and in previous publications that long-term cross-sector collaborations and policy changes are required to enable and sustain context-specific, technical solutions $[17,18]$. The convenience sampling approach of this paper limits its findings to the context of the case study. Nevertheless, we have used examples from literature to triangulate the main arguments of this paper and thus increase the theoretical generalizability of its recommendations.

\section{Conclusions}

A key lesson from the CoDEC and AfriCLP projects was that cross-sector collaboration across different levels of governance can lead to sustainable energy transitions. These collaborations can foster learning and help to build relationships and capacity. Stakeholders frame problems and devise potential solutions from different perspectives and dimensions. A multi-level, transdisciplinary co-design approach made it possible to understand what influences households' energy choices in Mathare informal settlement. The researchers assessed energy consumption at the household level by distinguishing between different end uses and energy choices. The study looked beyond the measurement of how much energy is used and sought to determine the drivers of energy consumption and fuel choices. The high cost of legal power connection led many Mathare residents to opt for dangerous indirect connections to cater for their lighting needs. It also contributed to residents' dependence on biomass fuels such as wood and charcoal for their cooking and heating. Overdependence on traditional fuels contributes to deforestation. Their combustion in poorly ventilated houses increases indoor air pollution and release of hydrocarbons into the atmosphere, thereby contributing to climate change. This is a similar scenario in other urban informal settlements such Enkanini informal settlement in South Africa.

In this paper, we looked at how to increase resilience in urban informal landscapes through sustainable energy transitions. We demonstrated how academics can facilitate the search for clean and sustainable energy solutions in urban informal settlements through transdisciplinary co-design approaches. Using a landscape governance approach, this paper determined that the failure of technical solutions in Mathare is proof of the futility of approaches that are implemented in isolation without consideration of all stakeholders at different sectors and landscape levels. Researchers can work closely with people in the targeted landscapes to help policymakers understand the critical underlying issues that influence choices and actions. Mathare residents were more open to interacting with researchers from the University, but reluctant to trust government agents due to the disputed nature 
of the settlement. The researchers were able to leverage this trust and bring together stakeholders from different backgrounds and sectors within the academic, government, community, and private sectors. The academics thus facilitated co-design processes where all stakeholders had a platform to share their ideas and potential solutions to the challenges. This set the basis for the development of energy and landscape policies that respond to the needs of the urban poor and guide sustainable energy transitions.

We therefore recommend landscape governance as a promising approach for integrating energy issues with other competing landscape interests, while also encouraging cross-sector collaboration. Although our findings are context-specific, we argue that the landscape governance approach has relevance in understanding the dynamics of other informal settlements in and beyond Kenya.

Author Contributions: A.A. was the principal investigator in the CoDEC and AfriCLP projects. All authors were actively involved in the writing of this paper in the following capacities-Conceptualization: A.A., P.N.; Writing of the original draft: P.N.; Mapping and Visualization: D.G.; Editing and initial review: A.A., G.O. All authors have read and agreed to the published version of the manuscript.

Funding: The writing of this paper did not receive any specific funding. However, the CoDEC research project referred to in this paper was supported by Leading Integrated Research for Agenda 2030 In Africa (LIRA2030) program from 2017 to 2019. LIRA2030 is a five-year program aimed at supporting collaborative research projects led by early career researchers across Africa. The program is being implemented by the International Science Council (ISC), in partnership with the Network of African Science Academies (NASAC), with support from the Swedish International Development Cooperation Agency (Sida). Additional funding for policy work in Kenya came from the Africa Climate Change Leadership (AfriCLP) program. AfriCLP is managed by University of Nairobi and is funded by the International Development Research Centre (IDRC).

Conflicts of Interest: The authors declare no conflict of interest.

\section{References}

1. Turley, L. The Landscape Approach: Moving Towards Sustainable Land Use Patterns. SSI Commentary, Report, Ottawa. 2016. Available online: https://www.iisd.org/ssi/wp-content/uploads/2019/09/LandscapeApproach.pdf (accessed on 7 January 2020).

2. Hofstad, H.; Tveit, S.; Stokke, B. Between development and protection: Different discourses in urban planning. Landsc. Res. 2014, 1-15. [CrossRef]

3. Brandon, K. Learning Labs: Creating Collaborative Ways to Address Climate Change in African Cities. Stockholm Environment Institute. Available online: https://www.sei.org/featured/learning-labs-creating-coll aborative-ways-to-address-climate-change-in-african-cities/ (accessed on 1 March 2020).

4. Government of Kenya. Kenya Vision 2030. 2007. Available online: https://kfcb.co.ke/wp-content/uploads/20 16/08/vision_2030.pdf (accessed on 9 April 2020).

5. UN Habitat. The challenge of slums: Global report on human settlements 2003. Manag. Environ. Qual. 2004, 15, 337-338. [CrossRef]

6. UNFPA. The State of the World Population 2018; United Nations Publisher: New York, NY, USA, 2018.

7. United Nations. World Urbanization Prospects; United Nations Publisher: New York, NY, USA, 2014.

8. Dodman, D.; Archer, D.; Mayr, M.; Engindeniz, E. Addressing the Most Vulnerable First: Pro-Poor Climate Action in Informal Settlements; UN-Habitat: Nairobi, Kenya, 2018. Available online: https://reliefweb.int/sites/reliefwe b.int/files/resources/Pro-poor\%20Climate\%20Action\%20in\%20Informal\%20Settlements\%20-\%20WEB.pdf (accessed on 27 December 2019).

9. Habitat UN. Slum Almanac 2015-2016: Tracking Improvement in the Lives of Slum Dwellers. Participatory Slum Upgrading Programme. 2016. Available online: https://unhabitat.org/slum-almanac-2015-2016 (accessed on 20 February 2020).

10. van Breda, J.; Swilling, M. The guiding logics and principles for designing emergent transdisciplinary research processes: Learning experiences and reflections from a transdisciplinary urban case study in Enkanini informal settlement, South Africa. Sustain. Sci. 2018, 14, 823-841. [CrossRef]

11. Williams, S.; Costa, M.M.; Sutherland, C.; Celliers, L.; Scheffran, J. Vulnerability of informal settlements in the context of rapid urbanization and climate change. Environ. Urban. 2019, 31, 157-176. [CrossRef]

12. Bai, X.; McPhearson, T.; Cleugh, H.; Nagendra, H.; Tong, X.; Zhu, T.; Zhu, Y.G. Linking urbanization and the environment: Conceptual and empirical advances. Annu. Rev. Environ. Resour. 2017, 42, 215-240. [CrossRef] 
13. WWF. WWF Living Forests Report: Chapter 2. Forests and Energy. 2011. Available online: https://wwf.panda. org/our_work/forests/forest_publications_news_and_reports/living_forests_report/energy_forests/(accessed on 5 March 2020).

14. Heiner, K.; Shames, S.; Spiegel, E. Integrated landscape management in Kenya: The state of the policy environment. In Proceedings of the 2016 World Bank conference on Land and Poverty, Washington, DC, USA, 14-18 March 2016.

15. Mansourian, S.; Walters, G.; Gonzales, E. Identifying governance problems and solutions for forest landscape restoration in protected area landscapes. PARKS 2019, 83-96. [CrossRef]

16. UNDP. Sustainable Energy. Available online: https://www.undp.org/content/undp/en/home/2030-agenda-fo r-sustainable-development/planet/sustainable-energy.html (accessed on 14 December 2019).

17. Kovacic, Z.; Musango, J.; Ambole, L.; Buyana, K.; Smit, S.; Anditi, C.; Mwau, B.; Ogot, M.; Lwasa, S.; Brent, A.C.; et al. Interrogating differences: A comparative analysis of Africa's informal settlements. World Dev. 2019, 122, 614-627. [CrossRef]

18. Ambole, A.; Musango, J.; Buyana, K.; Ogot, M.; Anditi, C.; Mwau, B.; Kovacic, Z.; Smit, S.; Lwasa, S.; Nsangi, G.; et al. Mediating household energy transitions through co-design in urban Kenya, Uganda and South Africa. Energy Res. Soc. Sci. 2019, 55, 208-217. [CrossRef]

19. Ambole, A.; Njoroge, P.; Outa, G.; Anditi, C. A case for providing electricity subsidies in urban informal settlements in Nairobi. KY Policy Briefs Realis. Vis. 2030 2020, 1, 21-22. Available online: https://uonresearch. org/journal/index.php/kpb/article/view/10/10 (accessed on 27 April 2020).

20. Cheseto, M. Challenges in Planning for Electricity Infrastructure in Informal Settlements: Case of Kosovo Village, Mathare Valley-Nairobi. Master's Thesis, University of Nairobi, Nairobi, Kenya, 2013.

21. Mandour, M. Sustainable informal housing by means of a better public space. Int. J. Arab Cult. Manag. Sustain. Dev. 2012, 2, 370. [CrossRef]

22. Sarmiento, H.; Tilly, C. Governance lessons from urban informality. Polit. Gov. 2018, 6, 199. [CrossRef]

23. Mwaniki, D.; Wamuchiru, E.; Mwai, B.; Opiyo, R.; Mwaniki, D. Urbanisation, informality, and housing challenges in Nairobi: A case of urban governance Failure. Cell 2015, 254, 917-960.

24. Sayer, J.; Sunderland, T.; Ghazoul, J.; Pfund, J.; Sheil, D.; Meijaard, E.; Venter, M.; Boedhihartono, A.K.; Day, M.; Garcia, C.; et al. Ten principles for a landscape approach to reconciling agriculture, conservation, and other competing land uses. Proc. Natl. Acad. Sci. USA 2013, 110, 8349-8356. [CrossRef] [PubMed]

25. Arts, B.; Buizer, M.; Horlings, L.; Ingram, V.; van Oosten, C.; Opdam, P. Landscape approaches: A state-of-the-art review. Annu. Rev. Environ. Resour. 2017, 42, 439-463. [CrossRef]

26. Prieur, M.; Luginbühl, Y.; Zoido, N.F.; de Montmollin, B.; Pedroli, B.; van Mansvelt, J.D.; Durosseau, S. Landscape and Sustainable Development: Challenges of the European Landscape Convention; Council of Europe Publishing: Strasbourg, France, 2006.

27. De Graaf, M.; Buck, L.; Shames, S.; Zagt, R. Assessing Landscape Governance: A Participatory Approach; Tropenbos International and EcoAgriculture Partners: Wageningen, The Netherlands, 2017.

28. van Assche, K.; Beunen, R. Shifting forms of landscape governance: Environmental policy, spatial planning and place branding strategies. In Working Papers in Evolutionary Governance Theory; International Institute for Innovation in Governance: Wageningen, The Netherlands, 2017; pp. 1-21. Available online: https://d1wqtxts1xzle7.cloudfront.net/53420070/Shifting_forms_of_landscape_governance_Flanders.pdf ?1496835825=\&response-content-disposition=inline\%3B+filename\%3DShifting_forms_of_landscape_go vernance_e.pdf\&Expires $=1592410420 \&$ Signature $=b V w d B k b q m L 4 s O o Y 9 C Z n \sim\{\} \sim\{\} \times N p D 0 R T R I 31 \mathrm{hhCE}$ $\sim\{\}$ TULNd86fxD \{\}Lg3EbS5JulJroo \{\}WQhTdxgFRhGWMy8uvJ2kOsthT7fKp8Orw8WN3FM \{\}p3rJT-u GFHMITZ8tpJcKlG0VDHnPC7K3fDJw8My0fHR8P6lhMrP8-nPjW6U9XorUMPe0k3eX3o2iD4ocZVJmP dY9S3uO-FBoChApWKBb77vK39WZsREdiv6hqpXNNWCXYHrVm9VfnJ8IsXIkBLs-VPZgQ3qvrjOQtGl kEhh3n2IX5vEdgViyG8KdDEi \{\}q7WPYFA-pf-Btb2oYBHclH-F74vFbABuHvj3Pz-JVsirOKfa51A_\&Key -Pair-Id=APKAJLOHF5GGSLRBV4ZA (accessed on 27 February 2020).

29. Syagga, P.; Malombe, J. Development and Management of Informal Housing in Kenya (Draft Report); Housing and Building Research Institute: Nairobi, Kenya, 1994.

30. Jones, P. Formalizing the informal: Understanding the position of informal settlements and slums in sustainable urbanization policies and strategies in Bandung, Indonesia. Sustainability 2017, 9, 1436. [CrossRef]

31. Andvig, J.; Barasa, T. A Political Economy of Slum Spaces: Mathare Valley; Norwegian Institute of International Affairs: Oslo, Norway, 2014. 
32. Kenya National Bureau of Statistics. Kenya Population and Housing Census; Kenya National Bureau of Statistics: Nairobi, Kenya, 2019; Volume I.

33. World Health Organization. Guidelines for Drinking Water Quality, Vol. 1, Recommendations, 4th ed.; World Health Organization: Geneva, Switzerland, 2011.

34. Njuguna, S.; Yan, X.; Gituru, R.; Wang, Q.; Wang, J. Assessment of macrophyte, heavy metal, and nutrient concentrations in the water of the Nairobi river, Kenya. Environ. Monit. Assess. 2017, 189. [CrossRef] [PubMed]

35. Mehnen, N.; Mose, I.; Strijker, D. Governance and sense of place: Half a century of a German nature park. Environ. Policy Gov. 2013, 23, 46-62. [CrossRef]

36. Mwaniki, D. Mapping Pollution in the Mathare River: An Analysis of Waste Disposal Patterns and River Pollution in an Informal Settlement. Ph.D. Thesis, University of Nairobi, Nairobi, Kenya, 2012.

37. Höppner, C.; Frick, J.; Buchecker, M. Assessing psycho-social effects of participatory landscape planning. Landsc. Urban Plan. 2007, 83, 196-207. [CrossRef]

38. Conniff, A.; Colley, K.; Irvine, K. Exploring landscape engagement through a participatory touch table approach. Soc. Sci. 2017, 6, 118. [CrossRef]

39. Ellis, E. Ecology in an anthropogenic biosphere. Ecol. Monogr. 2015, 85, 287-331. [CrossRef]

40. Fuentes, A. Human niche, human behaviour, human nature. Interface Focus 2017, 7. [CrossRef] [PubMed]

41. Van, C.; Seerp, W. Landscape Governance Capacity: Towards a Framework for Assessment and Strategic Guidance of Landscape Initiatives; Wageningen Centre for Development Innovation: Wageningen, The Netherlands, 2016.

42. Zhous, Z. Towards collaborative approach? Investigating the regeneration of urban village in Guangzhou, China. Habitat Int. 2014, 44, 297-305. [CrossRef]

43. Njenga, M. Banning Charcoal Isn't the Way to Go. Kenya Should Make it Sustainable. The Conversation. 2018. Available online: https://theconversation.com/banning-charcoal-isnt-the-way-to-go-kenya-should-m ake-it-sustainable-95610 (accessed on 19 December 2019).

44. Abdallah, H. Charcoal Traders Go to Uganda after Kenya Ban. The East African. 2019. Available online: https://www.theeastafrican.co.ke/business/Charcoal-traders-go-to-Uganda-after-Kenya-ban-/25605097292-lj12s4z/index.html (accessed on 20 December 2019).

45. Sovacool, B. The political economy of energy poverty: A review of key challenges. Energy Sustain. Dev. 2012, 16, 272-282. [CrossRef]

46. Kaygusuz, K. Energy for sustainable development: A case of developing countries. Renew. Sustain. Energy Rev. 2012, 16, 1116-1126. [CrossRef]

47. Horlings, L.; Battaglini, E.; Dessein, J. Cultural Sustainability and Regional Development. In Theories and Practices of Territorialisation, 1st ed.; Dessein, J., Battaglini, E., Horlings, L., Eds.; Routledge: London, UK, 2016; pp. 1-6.

48. Schatzki, T. The site of the social: A philosophical account of the constitution of social life and change. Choice Rev. Online 2003, 40, 3940-3946. [CrossRef]

49. van Assche, K.; Beunen, R.; Duineveld, M. Citizens, leaders and the common good in a world of necessity and scarcity: Machiavelli's lessons for community-based natural resource management. Ethics Policy Environ. 2016, 19, 19-36. [CrossRef]

50. Leibenath, M.; Lintz, G. Governance of energy landscapes between pathways, people and politics. Landsc. Res. 2018, 43, 471-475. [CrossRef]

51. Carvalho, A.; van Wessel, M.; Maeseele, P. Communication practices and political engagement with climate change: A research agenda. Environ. Commun. 2016, 11, 122-135. [CrossRef]

52. Sayer, J.; Margules, C.; Boedhihartono, A.; Dale, A.; Sunderland, T.; Supriatna, J.; Saryanthi, R. Landscape approaches; what are the pre-conditions for success? Sustain. Sci. 2014, 10, 345-355. [CrossRef]

53. The East African. Picking a Pathway through the Disappearing Forests of Kenya. 2018. Available online: https://www.theeastafrican.co.ke/scienceandhealth/Picking-a-pathway-through-the-disappearing-forests -of-Kenya-/3073694-4351716-rre74/index.html (accessed on 14 December 2019).

54. Natural Resources Alliance of Kenya. Kenya's Forest Cover. 2017. Available online: https://kenra.or.ke/keny as-forest-cover-2/ (accessed on 19 December 2019).

55. Asikainen, S.; Brites, C.; Plebańczyk, K.; Mijatović, L.; Soini, K. Culture in Sustainability: Towards a Transdisciplinary Approach; SoPhi: Jyväskylä, Finland, 2017. 
56. Horlings, L.G. The Role of Artists and Researchers in Sustainable Place-Shaping. In Culture in Sustainability: Towards a Transdisciplinary Approach; Asikainen, S., Brites, C., Plebańczyk, K., Mijatović, L.R., Soini, K., Eds.; SoPhi: Jyväskylä, Finland, 2017; pp. 131-143.

57. van Oosten, C. Forest landscape restoration: Who decides? A governance approach to forest landscape restoration. Nat. Conserv. 2013, 11, 119-126. [CrossRef]

58. Nadaï, A.; van der Horst, D. Introduction: Landscapes of energies. Landsc. Res. 2010, 35, 143-155. [CrossRef]

59. Butera, F.M.; Adhikari, R.S.; Caputo, P.; Facchini, A. The Challenge of Energy in Informal Settlements. A Review of the Literature for Latin America and Africa; Enel Foundation: Rome, Italy, 2015.

60. Fernandes, E. Regularization of Informal Settlements in Latin America; Lincoln Institute of Land Policy: Cambridge, UK, 2011.

61. Chepkwony, J. Charcoal Trade Thrives Despite Logging Ban: The Standard. 2019. Available online: https://www.standardmedia.co.ke/article/2001309788/charcoal-trade-thrives-despite-logging-ban (accessed on 20 December 2019).

62. Mansourian, S.; Sgard, A. Diverse interpretations of governance and their relevance to forest landscape restoration. Land Use Policy 2019, 1-8. [CrossRef]

63. Ferranti, F.; Turnhout, E.; Beunen, R.; Behagel, H. Shifting nature conservation approaches in Natura 2000 and the implications for the roles of stakeholders. J. Environ. Plan. Manag. 2014, 57, 1642-1657. [CrossRef]

64. Newig, J.; Fritsch, O. Environmental governance: Participatory, multi-level-and effective? Environ. Policy Gov. 2009, 19, 197-214. [CrossRef]

65. Beunen, R.; Opdam, P. When landscape planning becomes landscape governance, what happens to the science? Landsc. Urban Plan. 2011, 100, 324-326. [CrossRef]

66. Angelstam, P.; Munoz-Rojas, J.; Pinto-Correia, T. Landscape concepts and approaches foster learning about ecosystem services. Landsc. Ecol. 2019, 34, 1445-1460. [CrossRef]

67. Freeman, O.; Duguma, L.; Minang, P. Operationalizing the integrated landscape approach in practice. Ecol. Soc. 2015, 20. [CrossRef]

68. Reed, J.; van Vianen, J.; Barlow, J.; Sunderland, T. Have integrated landscape approaches reconciled societal and environmental issues in the tropics? Land Use Policy 2017, 63, 481-492. [CrossRef]

69. Sulistyawan, B.; Feger, C.; McKenzie, E.; Gallagher, L.; Verweij, P.; Verburg, R. Towards more effective landscape governance for sustainability: The case of RIMBA corridor, Central Sumatra, Indonesia. Sustain. Sci. 2019, 14, 1485-1502. [CrossRef]

70. Zoellner, J.; Schweizer-Ries, P.; Wemheuer, C. Public acceptance of renewable energies: Results from case studies in Germany. Energy Policy. 2008, 36, 4136-4141. [CrossRef]

71. Public Policy for Integrated Landscape Management in Kenya: Executive Summary of the Report from the National Dialogue. 24-26 June 2014. Available online: http://worldagroforestry.org/sites/default/files/Public\% 20Policy\%20Dialogue\%20for\%20Integrated\%20Landscape\%20Management\%20in\%20Kenya.pdf (accessed on 1 March 2020).

72. Broto, V.C. Energy landscapes and urban trajectories towards sustainability. Energy Policy 2017, 108, 755-764. [CrossRef]

(C) 2020 by the authors. Licensee MDPI, Basel, Switzerland. This article is an open access article distributed under the terms and conditions of the Creative Commons Attribution (CC BY) license (http://creativecommons.org/licenses/by/4.0/). 